Abstracta Iranica Abstranica

Revue bibliographique pour le domaine irano-aryen

Volume 29 | 2008

Comptes rendus des publications de 2006

\title{
Eftality (Očerki istorii). Sanki-Peterburg, Evropejskij Dom, 2006, 165 p. + 15 ill. [Les Hephtalites (Précis d'histoire)]
}

\section{Barbara Kaim}

\section{(2) OpenEdition}

1 Journals

\section{Édition électronique}

URL : http://journals.openedition.org/abstractairanica/25482

DOI : 10.4000/abstractairanica.25482

ISSN : 1961-960X

Éditeur :

CNRS (UMR 7528 Mondes iraniens et indiens), Éditions de l'IFRI

\section{Édition imprimée}

Date de publication : 15 mai 2008

ISSN : 0240-8910

Référence électronique

Barbara Kaim, « Eftality (Očerki istorii). Sanki-Peterburg, Evropejskij Dom, 2006, 165 p. + 15 ill. [Les Hephtalites (Précis d'histoire)] », Abstracta Iranica [En ligne], Volume 29 | 2008, document 53, mis en ligne le 15 septembre 2008, consulté le 26 septembre 2020. URL : http://journals.openedition.org/ abstractairanica/25482 ; DOI : https://doi.org/10.4000/abstractairanica.25482

Ce document a été généré automatiquement le 26 septembre 2020

Tous droits réservés 


\section{Eftality (Očerki istorii). Sanki- Peterburg, Evropejskij Dom, 2006, 165 p. +15 ill. [Les Hephtalites (Précis d'histoire)]}

\section{Barbara Kaim}

1 Le jeune chercheur turkmène dresse un bilan de l'état des connaissances sur ce peuple de nomades turcophones. En examinant les sources archéologiques et historiques et en présentant les nombreuses hypothèses en présence (émanant avant tout de chercheurs russophones bien connus), l'A. examine successivement (I) le problème de l'origine des Hephtalites, (II) l'histoire politique, (III) l'histoire socio-économique, (IV) la culture matérielle et spirituelle. Cette étape historique et culturelle est encore mal connue - et c'est la principale conclusion de la publication.

\section{INDEX}

Thèmes : 3.1. Est de l'Iran

\section{AUTEURS}

\section{BARBARA KAIM}

Université de Varsovie 